\title{
Formulasi dan evaluasi karakter fisik sediaan gel ekstrak etanol daun salam (Syzygium polyanthum)
}

Lalu Mukhlis Maqbul Sani ${ }^{1}$, Windah Anugrah Subaidah ${ }^{1 *}$, Yayuk Andayani ${ }^{1}$

${ }^{1}$ Program Studi Farmasi, Fakultas Kedokteran, Universitas Mataram, Mataram, Indonesia.

\section{DOI: https:/ / doi.org/10.29303/sjp.v2i1.84}

\section{Article Info}

Received : 2020-08-31

Revised : 2021-02-07

Accepted: 2021-04-26

\begin{abstract}
Bay leaves (Syzygium polyanthum) are known to have antioxidant effects that can neutralize free radicals found in the skin. The objectives of this research are to formulate the ethanol extract of bay leaves into gel formulation and evaluate the physical properties of gel formulation. Ethanol extract of bay leaves was obtained through the maceration method with $70 \%$ ethanol as a solvent. The thick ethanol extract of bay leaves was formulated into gel formulation with $\mathrm{CMC}$ - Na as a gelling agent, glycerin as a humectant, methyl paraben as a preservative, and aquadest as a solvent. After the freeze-thaw test was done, there was no change found in organoleptic but there were changes in $\mathrm{pH}$, spreadability, and adhesion. The $\mathrm{pH}$ of gel preparation before being in storage was 5 and after being in storage was 6 . In the spreadability, gel formulation spread 5,5 cm before being in the storage, and $5,1 \mathrm{~cm}$ after being in the storage. Gel adhesion has a sticky time of 8.35 seconds before in being storage and 8.45 seconds after being in storage.
\end{abstract}

Keywords: antioxidant, bay leaves, gel.

Citation: $\quad$ Sani, L.M.M., Subaidah, W.A., \& Andayani, Y. (2020). Formulasi dan evaluasi karakter fisik sediaan gel ekstrak etanol daun salam (Syzygium polyanthum). Sasambo Journal of Pharmacy, 2(1), 16-22. doi: https://doi.org/10.29303/sjp.v2i1.84

\section{Pendahuluan}

Daun salam (Syzygium polyanthum) banyak digunakan di Indonesia sebagai bumbu masak karena mempunyai aroma yang khas (Silalahi, 2017). Selain sebagai bumbu masak daun salam juga oleh masyakat digunakan untuk menurunkan kadar kolesterol (Wirawan, 2018), mengatasi kencing manis, menurunkan tekanan darah (Silalahi et al., 2020), menurunkan kadar gula darah (Taufiqurrohman, 2015), menurunkan kadar asam urat (Widoyono, et al., 2020), dan sebagai antibakteri (Tammi et al., 2019). Hal ini disebabkan oleh kandungan senyawa utama berupa flavonoid (Novira \& Febrina, 2018). Senyawa flavonoid dalam daun salam juga berperan sebagai antioksidan. Senyawa ini dapat melindungi tubuh dari serangan radikal bebas (Taroq et al., (2018).

Tubuh memerlukan antioksidan yang dapat membantu melindungi tubuh dari serangan radikal bebas yang dapat merusak membran sel normal dan merusak komposisi DNA sehingga dapat menyebabkan terjadinya suatu mutasi. Mutasi atau kerusakan komposisi DNA dapat menyebabkan penuaan dini, kerusakan kolagen dan kanker kulit (Helfrich et al., 2008).

Mekanisme antioksidan dalam menangkal radikal bebas adalah dengan menyumbangkan elektron pada radikal bebas untuk mencapai bentuk stabil, sehingga menghambat mekanisme oksidatif (Sarma et al., 2010). Antioksidan sintetik seperti BHA (butil hidroksi anisol) dan BHT (butil hidroksitoluen) dapat menimbulkan karsinogenesis (Kikuzaki et al, 2002). Oleh karena itu, diperlukan antioksidan alami sebagai sumber antioksidan dengan tingkat keamanan dan aktivitas yang tinggi. Ekstrak etanol daun salam diketahui memiliki $\mathrm{IC}_{50}$ sebesar $11 \mathrm{mg} / \mathrm{mL}$ yang merupakan aktivitas antioksidan kuat terhadap radikal bebas DPPH (Bahriul et al., 2014).

Berdasarkan uraian diatas, diketahui bahwa ekstrak etanol daun salam memiliki potensi sebagai antioksidan dengan aktivitas yang kuat (Hasanah, 
2015). Pemanfaatan daun salam selain dikonsumsi sebagai olahan makanan dan minuman, ekstrak etanol daun salam juga dapat diformulasikan sebagai zat aktif dalam sediaan semipadat yang tujuannya untuk menangkal radikal bebas pada kulit. Sediaan semipadat digunakan pada kulit berfungsi sebagai pembawa untuk obat-obat topikal, sebagai pelunak kulit atau sebagai pelindung (Wardani, 2009).

Antioksidan yang digunakan secara topikal memberikan dosis yang lebih tinggi pada kulit dibandingkan penggunaan oral. Sediaan antioksidan topikal, secara alami dapat menjadi nutrisi untuk melindungi kulit dari radikal bebas yang merusak (Diana \& Thaman, 2006). Sediaan topikal terdiri atas zat pembawa dan zat aktif. Suatu zat pembawa pada sediaan topikal, idealnya mudah dioleskan, mudah dibersihkan, tidak mengiritasi, selain itu zat aktif dalam pembawa juga mudah dilepaskan (Ansel, 2005). Salah satu sediaan semipadat yang dapat digunakan topikal adalah gel (Yanhendri \& Satya, 2012).

Gel merupakan salah satu sediaan obat yang banyak digunakan oleh masyarakat. Gel memiliki beberapa keuntungan dibanding sediaan topikal lain yaitu kemampuan penyebarannya baik pada kulit, tidak menghambat fungsi fisiologis kulit karena tidak melapisi permukaan kulit secara kedap dan tidak menyumbat pori-pori kulit, memberi sensasi dingin, mudah dicuci dengan air, memungkinkan pemakaian pada bagian tubuh yang berambut serta pelepasan obatnya baik (Sudjono et al., 2012). Berdasarkan uraian tersebut, maka penelitian ini bertujuan untuk melakukan formulasi dan evaluasi sifat fisik sediaan gel ekstrak etanol daun salam (Syzygium polyanthum).

\section{Metode}

\section{Alat dan Bahan}

Alat yang digunakan dalam penelitian ini adalah alat gelas, bejana, neraca analitik (Kern), seperangkat alat uji daya lekat, seperangkat alat uji daya sebar dan kertas $\mathrm{pH}$.

Bahan - bahan yang digunakan dalam penelitian ini adalah tanaman daun salam, etanol 70\% (Merck), natrium karboksi metil selulosa (CMC-Na) (Goodchem technology), gliserin (Wilmar), metil paraben (Pestanal) dan aquades.

\section{Pengumpulan dan Pengolahan Sampel}

Bahan utama yang dijadikan sebagai sumber zat aktif dalam penelitian ini yaitu daun salam yang sudah tua diperoleh dari desa Aikmel, Kabupaten Lombok Timur, Nusa Tenggara Barat. Daun salam kemudian dibersihkan menggunakan air. Daun salam yang sudah bersih, dikeringkan di bawah sinar matahari hingga kering dengan ditutupi kain. Kemudian dilakukan penghalusan daun salam menggunakan blender sampai menjadi serbuk.

\section{Pembuatan Ekstrak Daun Salam}

Pembuatan ekstrak etanol $70 \%$ daun salam menggunakan metode maserasi. Sebanyak $200 \mathrm{~g}$ serbuk daun salam dimasukkan ke dalam bejana kemudian diberi etanol 70\% dengan perbandingan 1:10 kali serbuk daun salam (2 L). Daun salam yang telah terendam etanol $70 \%$ didiamkan selama 24 jam di tempat terlindung cahaya, sambil berulang kali diaduk. Setelah 24 jam, kemudian dilakukan penyaringan dan dimaserasi sebanyak 2 kali. Selanjutnya filtrat dikumpulkan untuk dipekatkan dengan rotary evaporator pada suhu $50^{\circ} \mathrm{C}$ sehingga diperoleh ekstrak kental (Mindawarnis \& Desi, 2017).

\section{Skrining Fitokimia Ekstrak Daun Salam}

Uji flavonoid dilakukan dengan cara memasukkan sebanyak 0,5 ml ekstrak etanol daun salam ke dalam tabung reaksi. Lalu ditambahkan 5 sampai 10 tetes $\mathrm{HCl}$ encer dan sejumlah kecil $\mathrm{Zn}$ atau Mg. Kemudian larutan dididihkan selama beberapa menit. Flavonoid positif jika terjadi perubahan warna menjadi merah jambu atau coklat keruh (Gowri \& Vasantha, 2010).

\section{Pembuatan Gel}

Sediaan gel dibuat dengan komposisi sesuai tabel 1 dengan cara sebagai berikut: aquadest dipanaskan hingga suhu $70^{\circ} \mathrm{C}$ kemudian ditambahkan CMC-Na sambil diaduk hingga terbentuk massa yang homogen. Kedalam campuran tadi ditambahkan campuran metil paraben dan gliserin. Campuran tersebut diaduk hingga homogen. Setelah basis gel terbentuk ditambahkan ekstrak etanol daun salam (Khristantyo et al., 2011).

Tabel 1. Rancangan formulasi gel

\begin{tabular}{lcc}
\hline Bahan & Formulasi & Fungsi Bahan \\
\hline Ekstrak etanol daun salam & $3 \%$ & Bahan aktif \\
CMC-Na & $3 \%$ & Gelling agent \\
Metil paraben & $0,2 \%$ & Pengawet \\
Gliserin & $1 \%$ & Humektan \\
Aquades & Ad 100\% & Pelarut \\
\hline
\end{tabular}

\section{Uji Karakter Fisik Sediaan Gel Uji Organoleptis}

Pengamatan terhadap gel ekstrak etanol daun salam secara visual meliputi bau, warna dan bentuk dari sediaan gel.

\section{Uji Homogenitas}

Sejumlah gel ekstrak etanol daun salam dioleskan secukupnya pada plat kaca kemudian digosokkan dan diraba. Massa gel yang menunjukkan sifat homogen maka tidak terasa adanya bahan padat pada kaca (Trilestari, 2002).

\section{Pengukuran $\mathrm{pH}$}

Pengukuran $\mathrm{pH}$ sediaan gel ekstrak etanol daun salam dilakukan menggunakan kertas $\mathrm{pH}$ universal. 
Kertas $\mathrm{pH}$ universal dicelupkan ke dalam sediaan gel. Warna pada kertas $\mathrm{pH}$ yang timbul dicocokan dengan parameter $\mathrm{pH}$ yang terdapat pada alat. $\mathrm{pH}$ sediaan yang memenuhi kriteria $\mathrm{pH}$ fisiologi kulit yaitu dalam interval 4,5-6,5 (Tranggono, 2007).

\section{Uji Daya Sebar}

Uji daya sebar dilakukan untuk menjamin pemerataan gel saat diaplikasikan pada kulit yang dilakukan segera setelah gel dibuat. Sebanyak $0,5 \mathrm{~g}$ gel ekstrak daun salam ditimbang kemudian diletakkan di tengah kaca bulat berskala. Kaca bulat lain dan pemberat diletakkan di bagian atas sehingga berat kaca bulat dan pemberat $150 \mathrm{~g}$ diamkan selama 1 menit, kemudian catat diameter penyebarannya. Daya sebar gel yang baik antara 5-7 cm (Garg et al., 2002).

\section{Uji Daya Lekat}

Sebanyak 0,25 g gel ekstrak daun salam diletakkan di antara 2 gelas objek pada alat uji daya lekat, kemudian tekan dengan beban $1 \mathrm{~kg}$ selama 5 menit, angkat beban dan beri beban $80 \mathrm{~g}$ pada alat dan catat waktu pelepasan gel. Semakin lama daya lekat sediaan gel maka semakin baik sediaan gel tersebut (Miranti, 2009).

\section{Uji Kestabilan}

Sediaan gel ekstrak etanol daun salam diletakkan pada suhu $4^{\circ} \mathrm{C}$ selama 24 jam dilanjutkan dengan suhu $40^{\circ} \mathrm{C} 24$ jam berikutnya. Perlakuan tersebut adalah 1 siklus selama 48 jam. Pengujian dilakukan sebanyak 6 siklus kemudian diamati perubahan fisik dari sediaan gel pada awal dan akhir siklus yang meliputi organoleptis, $\mathrm{pH}$, homogenitas, daya sebar dan daya lekat (Dewi, 2016).

\section{Uji Akseptabilitas}

Prinsip uji akseptabilitas adalah sukarelawan diminta untuk mencoba produk gel ekstrak etanol daun salam, kemudian diminta memberikan tanggapan atau penilaian terhadap produk yang dicoba tanpa membandingkan dengan produk lainnya. Secara umum uji akseptabilitas digunakan untuk mengetahui tingkat kesukaan konsumen terhadap produk dan menilai produk secara organoleptik (Laksmi et al., 2007).

\section{Uji Iritasi}

Pengujian ini dilakukan terhadap 20 orang relawan dengan kontrol positif yaitu ekstrak murni tanpa campuran bahan pembuat gel lainnya lalu diamati gelaja yang timbul. Apabila terjadi iritasi akan ditunjukkan dengan adanya reaksi kulit setelah sediaan dioleskan pada kulit. Iritasi yang terjadi sesaat setelah pelekatan disebut iritasi primer, sedangkan jika terjadi setelah beberapa jam pelekatan disebut iritasi sekunder (Sutriningsih et al., 2018).

\section{Analisis Data}

Data yang didapatkan yaitu data hasil uji sifat fisik sediaan gel diantaranya pengukuran daya sebar, daya lekat, dan $\mathrm{pH}$. Data tersebut dibandingkan dengan syarat masing-masing uji. Data hasil uji daya lekat dan daya sebar juga di Uji t-Test.

\section{Hasil dan Pembahasan}

Determinasi terhadap sampel dilakukan di Fakultas Matematika dan Ilmu Pengetahuan Alam Universitas Mataram yang bertujuan untuk memastikan bahwa sampel yang diteliti adalah benar daun salam (Syzygium polyanthum). Berdasarkan surat keterangan identifikasi nomor: 66/UN18.7/LB/2019 menunjukkan bahwa sampel yang digunakan adalah benar daun tumbuhan salam dengan nama ilmiah Syzygium polyanthum.

Pembuatan ekstrak etanol daun salam menggunakan metode maserasi dengan pelarut etanol $70 \%$. Pelarut etanol 70\% dipilih karena sifat kepolaran etanol yang dapat menarik senyawa flavonoid (Gillespie \& Paul, 2001). Riwayanti et al., (2020) mengisolasi senyawa flavonoid menggunakan pelarut etanol $70 \%$ dan didapatkan kandungan flavonoid yang lebih tinggi dibandingkan pelarut lainnya. Hasil ekstraksi dihilangkan pelarutnya sehingga diperoleh ekstrak kental sebanyak $55 \mathrm{~g}$ dengan rendemen ekstrak sebesar $27,5 \%$. Data organoleptis ekstrak daun salam diperoleh bau ekstrak khas daun salam, berbentuk kental dan berwarna coklat.

Skrining flavanoid yang dilakukan pada ekstrak etanol daun salam menunjukkan perubahan warna larutan dari hijau tua menjadi merah. Hal ini mengindikasikan terdapat kandungan flavanoid dalam ekstrak etanol daun salam. Hal ini sesuai dengan penelitian Yunus (2015) yang juga menyatakan terjadi perubahan warna larutan menjadi menjadi merah pada uji senyawa flavonoid daun salam. Perubahan warna merah pada uji flavonoid disebabkan oleh penambahan $\mathrm{HCl}$ dan $\mathrm{Mg}$. Tujuan penggunaan logam $\mathrm{Mg}$ dan $\mathrm{HCl}$ adalah untuk mereduksi inti benzopiron yang terdapat dalam struktur flavonoid sehingga terbentuk garam flavilium berwarna merah atau jingga (Lathifah, 2008).

Formulasi sediaan gel dilakukan dengan menggunakan ekstrak etanol daun salam (Syzygium polyanthum) sebagai zat aktif, CMC-Na sebagai basis pembentuk gel, metil paraben sebagai pengawet, gliserin sebagai humektan, dan aquades sebagai pelarut. Pembuatan gel ini diawali dengan pengembangan $\mathrm{CMC}-\mathrm{Na}$ yang merupakan polimer turunan selulosa yang cepat mengembang bila diberikan bersama air panas (Aponno et al., 2014). Penambahan metil paraben diperlukan dalam formulasi gel sebagai anti mikroba karena tingginya kadar air pada sediaan gel yang dapat menyebabkan terjadinya kontaminasi mikroba. Adapun gliserin yang berfungsi untuk mempertahankan kelembapan pada sediaan dan juga dapat membuat sediaan menjadi 
jernih dan transparan (Asngad et al., 2018). Basis yang terbentuk kemudian ditambahkan ekstrak daun salam kemudian diaduk hingga homogen. Hasil sediaan gel ekstrak etanol daun salam dapat dilihat pada gambar 1 .

Tabel 2. Hasil evaluasi sediaan gel ekstrak etanol daun salam

\begin{tabular}{lcc}
\hline \multirow{2}{*}{ Parameter } & \multicolumn{2}{c}{ Siklus } \\
\cline { 2 - 3 } & Ke-0 & Ke-6 \\
\hline Bau & khas daun salam & khas daun salam \\
Warna & coklat & coklat \\
Bentuk & gel & gel \\
Homogenitas & homogen & homogen \\
pH & 5 & 6 \\
Daya sebar $(\mathrm{cm})$ & $5,5 \pm 0,14$ & $5,1 \pm 0,14$ \\
Daya lekat (detik) & $8,35 \pm 2,14$ & $8,45 \pm 4,32$ \\
\hline
\end{tabular}

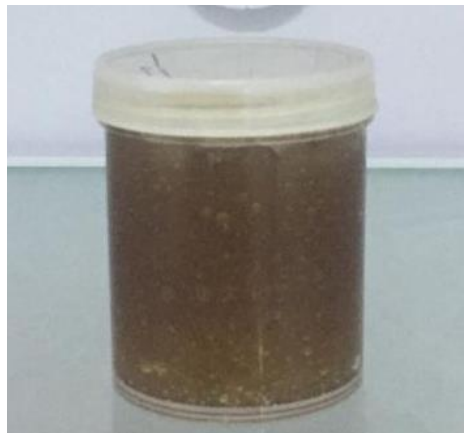

Gambar 1. Gel ekstrak etanol daun salam (Syzygium polyanthum)

Uji organoleptis dilakukan untuk mendeskripsikan sediaan gel secara kasat mata. Dari hasil pengamatan didapatkan warna, bentuk, dan bau seperti yang tertera pada tabel 2 . Warna coklat pada gel ini berasal dari ekstrak kental daun salam. Warna coklat pada ekstrak karena terekstraksinya senyawa pewarna polar alami terutama dari polimer fenol atau polifenol seperti tanin, melanin, lignin dan kuinon pada tanaman (Murhadi et al., 2007). Gel ini memiliki bau khas daun salam yang berasal dari ekstrak kental daun salam yang digunakan. Bentuk sediaan ini adalah gel, dimana bentuk tersebut sudah sesuai dengan bentuk sediaan gel yaitu sediaan semipadat.

Pengamatan kestabilan dengan uji freeze thaw menunjukkan pada siklus ke-6 tidak terjadi perubahahan bau, warna dan bentuk sediaan. Pada siklus ke-6 juga terlihat tidak terjadi pemisahan antara basis gel dan ekstrak etanol daun salam. Dari hasil pengamatan organoleptis diketahui bahwa sediaan gel stabil.

Pengujian homogenitas sediaan gel ekstrak etanol daun salam bertujuan untuk mengetahui apakah sediaan telah tercampur merata (homogen). Hasil uji homogenitas tertera pada tabel 2. Berdasarkan pengamatan yang dilakukan pada siklus ke-0 dan ke-6, sediaan yang diperoleh memiliki karakteristik yang homogen. Kehomogenitas sediaan ditandai dengan tidak adanya partikel kasar di dalam sediaan (Trilestari, 2002). Hal ini sesuai dengan penelitian Nutrisia (2015) yang juga menyatakan karateristik yang homogen pada gel dengan basis CMC-Na pada saat sebelum dan sesudah penyimpanan gel.

Pengujian $\mathrm{pH}$ pada sediaan gel ekstrak etanol daun salam dilakukan agar $\mathrm{pH}$ sediaan sesuai dengan $\mathrm{pH}$ fisiologis kulit manusia. $\mathrm{pH}$ sediaan yang sama dengan $\mathrm{pH}$ kulit akan memberikan kenyamanan penggunaan sediaan gel. $\mathrm{pH}$ gel yang terlalu asam dapat mengiritasi kulit sedangkan $\mathrm{pH}$ yang terlalu basa akan menyebabkan kulit kering dan cenderung untuk terkelupas. Syarat $\mathrm{pH}$ untuk sediaan topikal yang sesuai dengan $\mathrm{pH}$ fisiologis kulit yaitu antara 4,5-6,5 (Tranggono, 2007). Hasil pengukuran $\mathrm{pH}$ gel ekstrak etanol daun salam tersaji pada tabel 2 dan menunjukkan perubahan $\mathrm{pH}$. Peningkatan $\mathrm{pH}$ pada siklus ke-6 disebabkan oleh gel mengalami hidrolisis kation. Meski demikian, sediaan gel tersebut sudah memenuhi syarat $\mathrm{pH}$ untuk sediaan topikal yaitu antara 4,5 - 6,5 (Young, 2004). Hal ini sesuai dengan penelitian Ida \& Noer (2012) yang menyatakan terjadi perubahan $\mathrm{pH}$ pada sediaan gel setelah penyimpanan karena pengaruh faktor seperti suhu penyimpanan dan masuknya gas-gas yang dapat merubah $\mathrm{pH}$ sediaan gel.

Uji daya sebar dilakukan untuk mengetahui kemampuan sediaan untuk menyebar saat dioleskan pada kulit (Subaidah et al., 2020). Hasil pengukuran daya sebar gel ekstrak etanol daun salam tersaji pada tabel 2. Penurunan daya sebar disebabkan oleh meningkatnya viskositas sediaan. Peningkatan viskositas sediaan disebabkan oleh penguapan etanol yang berada dalam sediaan (Kuncari et al., 2014). Data uji daya sebar dianalisis menggunakan t-Test, diketahui memiliki nilai signifikansi kurang dari 0,05 yaitu 0,024. Nilai tersebut menunjukkan adanya perbedaan signifikan antar hasil uji daya sebar gel. Meski demikian, nilai daya sebar sediaan gel tersebut sudah memenuhi persyaratan daya sebar sediaan topikal yaitu 5-7 cm (Garg et al., 2002). Hasil evaluasi daya sebar tersebut sesuai dengan penelitian Lena \& Nining (2015) yang melakukan penelitian terhadap stabilitas gel menunjukkan bahwa terjadi penurunan daya sebar gel setelah penyimpanan karena terjadi peningkatan viskositas gel.

Pengujian daya lekat gel dilakukan untuk mengetahui lama waktu sediaan gel melekat pada kulit. Semakin lama daya lekat sediaan gel maka semakin baik sediaan gel tersebut karena semakin banyak zat aktif yang dapat berdifusi pada kulit sehingga efek yang diperoleh lebih optimal (Pujiastuti \& Kristiani, 2019). Hasil uji daya lekat sediaan gel 
ekstrak etanol daun salam tertera pada tabel 2. Hasil pengujian daya lekat memperlihatkan perbedaan durasi waktu lekat sediaan gel dan memiliki perbedaan yang signifikan setelah perhitungan menggunakan tTest karena memiliki nilai signifikasi kurang dari 0,05 yaitu 0,004. Peningkatan daya lekat terjadi karena adanya peningkatan viskositas selama penyimpanan sediaan gel. Peningkatan viskositas ini disebabkan oleh menguapnya etanol di dalam sediaan gel pada saat penyimpanan (Kuncari et al., 2014).

Hasil uji akseptabilitas dilakukan terhadap 20 sukarelawan. Hasil pengujian menunjukkan bahwa sebanyak $100 \%$ orang menyukai tekstur gel, sebanyak $70 \%$ orang menyukai warna gel, dan sebanyak $95 \%$ orang menyukai bau gel.

Pengujian iritasi bertujuan untuk mengetahui keamanan sediaan gel ekstrak etanol daun salam jika digunakan dengan parameter iritasi apabila diaplikasikan pada kulit. Hasil pengujian menunjukkan bahwa sediaan gel tidak menunjukkan reaksi iritasi terhadap 20 sukarelawan. sehingga dapat disimpulkan bahwa sediaan gel tersebut aman digunakan pada kulit (Laksmi, 2007).

\section{Simpulan}

Berdasarkan hasil penelitian yang telah dilakukan dapat disimpulkan bahwa ekstrak etanol daun salam dapat diformulasikan kedalam bentuk sediaan gel dengan CMC-Na sebagai gelling agent. Hasil evaluasi sifat fisik sediaan gel ekstrak etanol daun salam menunjukkan sediaan telah memenuhi persyaratan sediaan gel.

\section{Daftar Pustaka}

Ansel, H. C. (2005) Pengantar Bentuk Sediaan Farmasi. Diterjemahkan oleh Ibrahim, F. Jakarta: UI Press.

Aponno, J.V., Yamlean, P.V.Y., \& Supriati, H.S. (2014). Uji efektivitas sediaan gel ekstrak etanol daun jambu biji (Psidium guajava Linn) terhadap penyembuhan luka yang terinfeksi bakteri Staphylococcus aureus pada kelinci (Orytolagus cuniculus). Jurnal Ilmiah Farmasi. 3(3), 279-286. Retrieved from https://ejournal.unsrat.ac.id/index.php/pharmac on/article/view/5444

Asngad, A., Aprilia B. R., \& Nopitasari. (2018). Kualitas gel pembersih tangan (hand sanitizer) dari ekstral batang pisang dengan penambahan alkohol, trklosan dan gliserin yang berbeda dosisnya. Bioeksperimen. $\quad 4(2), \quad 61-70 . \quad$ DOI: https://doi.org/10.23917/bioeksperimen.v4i2.6888
Bahriul, P., Nurdin, R., \& Anang W. (2014). Uji aktivitas antioksidan ekstrak daun salam (Syzygium polyanthum) dengan menggunakan 1,1-Difenil-2Pikrilhidrazil. Jurnal Akademia Kimia. 3(3), 143-149. Retrieved from http://jurnal.untad.ac.id/jurnal/index.php/JAK/ article/view/7794/6149

Dewi, S. (2016). Formulasi dan uji stabilitas fisik gel ekstrak etanol daun kemangi (Ocimum sanctum L.) sebagai sediaan hand sanitizer. Universitas Islam Negeri Makassar, Makassar.

Diana, D. Z., \& Thaman, A. L. (2006). Cosmetic Formulation of Skin Care Product. New York: Taylor and Francis Group.

Garg, A., Aggarwal, D., Garg, S., \& Sigla, A.K. (2002). Spreading of semisolid formulation an update. India: Pharmaceutical Tecnology. Retrieved from https://www.researchgate.net/publication/279595 351_Spreading_of_semisolid_formulations_An_up date

Gillespie, R.J. \& Paul. (2001). Chemical Bonding and Molecular Geometry. London: Oxford University Press.

Hasanah, N. (2015). Aktivitas antioksidan ekstrak etanol daun salam. Jurnal Pena Medika. 5(1), 55-59. Retrieved from https://jurnal.unikal.ac.id/index.php/medika/arti cle/view/345/325

Helfrich, Y., Sachs, D., \& Voorhees, J. (2008). Overview of skin aging and photoaging. Dermatol Nurs, 20(3).

Ida, N. \& Noer S. F. (2012). Uji stabilitas fisik gek ekstrak lidah buaya (Aloe vera L.). Majalah Farmasi dan Farmakologi. 16(2), 79-84.

Khristantyo, Y., Astuti, I.Y., \& Suparman. (2011). Profil sifat fisik gel antioksidan ekstrak buncis (Phaseolus vulgaris L) dengan basis CMC-Na. Jurnal Farmasi Indonesia. 8(1), 125-39. DOI: 10.30595/pji.v8i1.602

Kikuzaki, H., Hisamoto, M., Hirose, K., Akiyama, K., \& Taniguchi, H. (2002). Antioxidants Properties of Ferulic Acid and Its Related Compound. Journal Agric Food Chem. 50(7), 2161-2168. DOI: 10.1021/jf011348w

Kuncari, E. S., Iskandarsyah \& Pratiwi. (2014). Evaluasi, uji stabilitas fisik dan sinersis sediaan gel yang mengandung minoksidil, apigenin dan perasan 
herba seledri (Apium graveolens L.). LIPI. 42(4), 213. Retrieved from http://ejournal.litbang.kemkes.go.id/index.php/B PK/article/view/3659

Laksmi, B. S., Yasni, S., \& Sudirman, I. (2007). Mekanisme antibakteri $\mathrm{lb}$. plantarumkik dan monoasilgliserol minyak kelapa terhadap bakteri patogen pangan. Jurnal Teknologi dan Industri Pangan. 8(2), 126.

Lathifah, Q.A.Y., 2008. uji efektifitas ekstrak kasar senyawa antibakteri pada buah belimbing wuluh (Averrhoa bilimbi 1.) dengan variasi pelarut. Universitas Islam Negeri Malang, Malang.

Lena, M., \& Nining, S. (2015). Formulasi gel ekstrak etanol kulit buah manggis (Garcinia mangostana 1.) dengan variasi gelling agent sebagai sediaan luka bakar. Pharmaciana. 5(1), 43-52. DOI: http://dx.doi.org/10.12928/pharmaciana.v5i1.228 5

Mindawarnis, M., \& Desti, H. (2017). Formulasi sediaan tablet ekstrak daun nangka (artocarpus heterophytus l.) dengan variasi polivis pirolidon (pvp) sebagai pengikat dan evaluasi sifat fisiknya. Jurnal Kesehatan. 129(1), 12-26. Retrieved from https://jurnal.poltekkespalembang.ac.id/index.ph $\mathrm{p} / \mathrm{JPP} /$ article/view/12

Miranti, L. (2009). Pengaruh konsentrasi minyak atsiri kencur (Kaemferia galangal) dengan basis salep larut air terhadap sifat fisik salep dan daya hambat bakteri Staphylococcus aureus secara in vitro. Univeritas muhammadiyah surakarta, Surakarta. Retrieved from http://eprints.ums.ac.id/id/eprint/3269

Murhadi, Suharyono, A., S., \& Susilawati (2007). Aktivitas antibakteri daun salam (Syzygium polyanta) dan daun pandan (Pandanus amarylifolius). Jurnal Teknologi dan Pangan. 12(1), 17-24. Retrieved from

https://journal.ipb.ac.id/index.php/jtip/article/vi $\underline{\mathrm{ew} / 371}$

Novira, P., P., \& Febrina, E. (2018). Review artikel: tinjauan aktivitas farmakologi ekstrak daun salam (Syzygium polyanthum (Wight.) Walp). Farmaka. 16(2), 288-297.

Nutrisia, A., S. (2015). Formulasi dan uji stabilitas fisik sediaan gel ekstrak daun ketepeng cina (Cassia alata L.). Jurnal Kefarmasian Indonesia. 5(1), 80. Retrieved from

https://www.neliti.com/id/publications/105051/ formulasi-dan-uji-stabilitas-fisik-sediaan-gelekstrak-daun-ketepeng-cina-cassia\#cite

Pujiastuti, A., \& Kristiani, M. (2019). Formulasi dan uji stabilitas mekanik hand and body lotion sari buah tomat (Licopersicon esculentum mill) sebagai antioksidan. Jurnal Farmasi Indonesia. 16(1), 42-55. DOI: $10.31001 /$ jfi.v16i1.468

Riwanti, P., Izazih, F., Amaliyah. (2020). Pengaruh perbedaan konsentrasi etanol pada kadar flavonoid total ekstrak etanol 50,70 dan 96\% Sargassum polycystum dari madura. Journal of Pharmaceutical Care Anwar Medika. 2(2), 82-95. DOI: http://dx.doi.org/10.36932/jpcam.v2i2.1

Sarma, A.D., Mallick, A.R., \& Ghosh, A.K. (2010). Free Radicals and Their Role in Different Clinical Conditions. Jurnal Internasional. 1(3), 185-192.

Silalahi, K., Nainggolan, N., Simanjuntak, S., \& Ginting, F. (2020). The effect of brushed salam leaf on the reduction of high blood pressure in hypertension patients. Jurnal Penelitian Perawat Profesional, 2(4), 431-436. https://doi.org/10.37287/jppp.v2i4.201

Silalahi, M. (2017), Syzygium polyanthum (Wight) Walp. (botani, metabolit sekunder dan pemanfaatan). JDP. 10(1), 1-16.

Subaidah, W.A., Hajrin, W., \& Juliantoni, H. (2020). Formulasi dan evaluasi sifat fisik lotion ekstrak etanol daun kemuning (Murraya paniculata (l) jack) dan daun lidah buaya (Aloe vera Linn). Sasambo Journal of Pharmacy. 1(1), 12-16. Retrieved from https://iffk.unram.ac.id/index.php/sjp/article/vi ew/6

Sudjono, T.A., Honniasih, M., \& Pratimasari, Y.R. (2012). Pengaruh konsentrasi gelling agent karbomer 934 dan hpmc pada formulasi gel lendir bekicot (Achatina fulica) terhadap kecepatan penyembuhan luka bakar pada punggung kelinci. Pharmacon Pharmaceutical Journal of Indonesia. 13 (1), 6-11. DOI: https://doi.org/10.23917/pharmacon.v13i1.20

Sutriningsih, Sagala, Z., \& Marhamah. (2018). Formulation and irritation test of antibacterial gel from star fruit leaves (Averrhoa bilimbi Linn.) ethanol extracted againts bacteria Staphylococcus aureus and Pseudomonas aeruginosa. Jurnal Sains and Teknologi. 2(1), 448-458. Retrieved from 
https://ojs.uph.edu/index.php/FaSTJST/article/v iew/1011

Tammi, A., Apriliana, E., Soleha, T., U., \& Ramadhian, M., R. (2018). Potensi ekstrak daun salam (Syzygium polyanthum [Wight.] Walp.) sebagai antibakteri terhadap Staphylococcus aureus secara in vitro. Jurnal Kesehatan dan Agromedicine. 5(2), 562-566. . Retrieved from https://juke.kedokteran.unila.ac.id/index.php/agr o/article/view/2113/pdf.

Taroq, A., Kamari, F., E., Aouam, I., Atki, Y., E., Lyoussi, B., \& Abdellaoui, A. (2018). Antioxidant activities and total phenolic and flavonoid content variations of leaf extracts of Laurus nobilis 1 . From morocco. Asian Journal of Pharmaceutical and Clinical Research. 11(12), 540-543. DOI: http://dx.doi.org/10.22159/ajpcr.2018.v11i12.2974 7

Taufiqurrohman. (2015). Indonesian bay leaves as antidiabetic for type 2 diabetes mellitus. J Majority. 4(3), 102-108. Retrieved from https://juke.kedokteran.unila.ac.id/index.php/ma jority/article/view /558

Tranggono, L. (2007). Buku Pegangan Ilmu Pengetahuan Osmetik. Jakarta: PT. Gramedia Pustaka Utama.

Trilestari. (2002). Hand \& body lotion: pengaruh penambahan nipagin, nipasol dan campuran keduanya terhadap stabilitas fisika dan efektifitasnya sebagai anti jamur. Universitas Gadjah Mada, Yogyakarta.

Wardani, L.P. (2019). Efek penyembuhan luka bakar gel ekstrak etanol daun siri (Piper betle) pada kulit punggung kelinci. Universitas Muhammadiyah Surakarta, Surakarta.

Widoyono, Aryani, A., \& Sartagus, R., A. (2020). Pengaruh rebusan daun salam terhadap penurunan kadar asam urat pada lansia. Jurnal Perawat Indonesia. 4(2), 413-423.

Wirawan, W. (2018). Uji efektivitas fraksi daun salam terhadap kadar kolesterol total tikus putih jantan hiperkolesterolemia-diabetes. Jurnal Mandala Pharmacon Indonesia. 4(1), 74-82. Retrieved from www.jurnal-pharmaconmw.com/jmpi

Yanhendri \& Satya., Y (2012). Berbagai bentuk sediaan topikal dalam dermatologi. Jurnal CDK. 39(6), 423.
Young, J. (2004). Triethanolamine. Journal of Chemical Education. 81(1), Hal. 24.

Yunus, N. (2015). Identifikasi senyawa flavonoid ekstrak etanol daun salam (Syzygium polyanthum) asal gorontalo dengan menggunakan metode kromatografi lapis tipis. Universitas Negeri Gorontalo, Gorontalo. 